\title{
Levels of carnitine and acylcarnitines in reconstituted red blood cell samples washed with different concentrations of saline solutions
}

\author{
José Henry Osorio, PhD¹, Morteza Pourfarzam, PhD²
}

\section{SUMMARY}

Objective: To evaluate the percentage of carnitine and acylcarnitines remaining in red blood cells after washing them with different concentrations of saline solution.

Materials and methods: Human blood samples were centrifuged and the blood cells were washed with different saline solutions. The final pellet was resuspended in PBS for card preparation and tandem mass spectrometry analysis.

Results: It was found that carnitine, as well as short-chain, medium-chain, and long-chain acylcarnitines remain in red blood cells at average percentages of 19.3;34;34; and 32\%, respectively. Significant differences were found for carnitine and acylcarnitine levels in blood washed with an isotonic solution compared to their levels using several hypotonic solutions $(\mathrm{p}<0.05)$.

Conclusion: Because carnitine and acylcarnitines remained associated with the blood cells, we recommend using whole blood to measure these metabolites.

Colomb Med. 2010; 41: 344-8

Keywords: Carnitine; Acylcarnitines; Acyl-CoA; Tandem mass spectrometry; Red blood cells; Metabolism.

\begin{abstract}
Niveles de carnitina y acilcarnitinas en muestras de glóbulos rojos reconstituidos y lavados con solución salina a diferentes concentraciones
\end{abstract}

\section{RESUMEN}

Objetivo: Evaluar el porcentaje de carnitina y acilcarnitinas que permanece en los glóbulos rojos, luego de lavarlos con solución salina a diferentes concentraciones.

Materiales y métodos: Muestras de sangre humana fueron centrifugadas y los glóbulos rojos fueron lavados con solución salina a diferentes concentraciones. El pellet obtenido, fue resuspendido en PBS para preparación de tarjetas y análisis por espectrometría de masa en tandem.

Resultados: La carnitina, así como las acilcarnitinas de cadena corta, cadena media y cadena larga, permanecen en los glóbulos rojos a porcentajes promedio de 19,$3 ; 34 ; 34$; and 32\%, respectivamente. Se encontró diferencia significativa al comparar los niveles de carnitina y acilcarnitinas de sangre lavada con una solución salina isotónica $v s$. varias hipotónicas $(\mathrm{p}<0.05)$.

Conclusión: debido a que la carnitina y las acilcarnitinas permanecen en los glóbulos rojos, se recomienda el uso de sangre entera para medir los niveles de estos metabolitos.

Colomb Med. 2010; 41: 344-8

Palabras clave: Carnitina; Acylcarnitinas, Acyl-CoA; Espectrometría de masa en tándem;

Glóbulos rojos; Metabolismo.

Carnitine and acylcarnitine identification in body fluids by using tandem mass spectrometry was developed in the late $1980 \mathrm{~s}^{1,2}$ and represents a valuable tool for the diagnosis of some inherited metabolic defects, which are difficult to diagnose by classical chromatographic

method. The method has the potential of effectively screening for at least a dozen other disorders ${ }^{3-7}$. Some authors suggest that a plasma carnitine and acylcarnitine profile should be performed in all patients presenting acute episode of hypoketotic hypoglycemia, Reye

1. Professor, Department of Basic Sciences for Health, Research Labortory in Clinical Biochemistry and Molecular Pathology, Universidad de Caldas, Manizales, Colombia. e-mail: jose.osorio_o@ucaldas.edu.co

2. Lecturer, Spence Biochemical Genetics Unit, Royal Victoria Infirmary, Newcastle upon Tyne, England.

e-mail: M.pourfarzam@ncal.ac.uk

Received for publication September 8, 2009 Accepted for publication April 26, 2010 
syndrome, hypertrophic cardiomyopathy, pericardial effusion, cardiac failure, or rapid unexpected death during the neonatal period or during infancy; also, heart beat disorders during neonatal period, hypotonia with unexplained failure to thrive, retinitis pigmentosa, or even muscle pain triggered by exercise ${ }^{8}$. Measurement of acylcarnitines by using tandem mass spectrometry has been reported in whole blood ${ }^{9}$, plasma $^{10}$, urine $^{11}$, amniotic fluid $^{12}$, and bile ${ }^{13}$. There has been a permanent question about the ideal fluid for carnitine and acylcarnitine measurement. This study evaluates the percentage of carnitine and acylcarnitines remaining in red blood cells, after washing with different concentrations of saline solution to establish the recommended fluid for carnitine and acylcrnitine analysis by tandem mass spectrometry.

\section{MATERIALS AND METHODS}

The current study is experimental. All the chemicals used were of analytical grade. Unlabelled acylcarnitine and deuterated carnitine and acylcarnitines $\left(\left[\mathrm{d}_{3}\right] \mathrm{C}_{2} \mathrm{cn}\right.$, $\left[\mathrm{d}_{9}\right] \mathrm{C}_{2} \mathrm{cn},\left[\mathrm{d}_{3}\right] \mathrm{C}_{3} \mathrm{cn},\left[\mathrm{d}_{3}\right] \mathrm{C}_{8} \mathrm{cn},\left[\mathrm{d}_{9}\right] \mathrm{C}_{8} \mathrm{cn},\left[\mathrm{d}_{3}\right] \mathrm{C}_{16} \mathrm{cn}$, $\left[\mathrm{d}_{3}\right] \mathrm{C}_{16} \mathrm{cn}$ ) were obtained from Cambridge isotopes laboratories (Andover, MA, USA). Butanolic HCL was prepared by passing HCL gas through anhydrous nbutanol (Sigma-aldrich Company, Ltd., Poole, UK) for $30 \mathrm{~min}$. The concentration of the acid was determined by back tritiation and adjusted.

Blood specimens and card preparation. Blood samples used in this study were from ten adult healthy volunteers who signed written consent. Blood was collected into a tube containing EDTA $(23.5 \mu \mathrm{mol} /$ tube). Aliquots of $20 \mathrm{ml}$ were spotted on specimen collection filter paper cards $\left(\mathrm{N}^{\circ} 903,1.88-\mathrm{mm}\right.$ thick; Schleicher \& Schuell, Dassel, Germany), dried overnight at room temperature, vacuum sealed, and kept in the freezer $\left(-80^{\circ} \mathrm{C}\right)$ until analysis.

Extraction of blood acylcarnitines using microtiter plates. Blood spots were punched from the card, (6.35mm diameter corresponding to $12 \mathrm{ml}$ of whole blood, as described (Hannon et al., 1997) and placed into microtiter plates ( 96 samples for each plate). A total of $100 \mathrm{ml}$ of the internal standard (containing the following labeled acylcarnitines in $100 \mathrm{ml}$ methanol: $\left[\mathrm{d}_{3}\right] \mathrm{cn}, 360$ pmol; $\left[\mathrm{d}_{3}\right] \mathrm{C}_{2} \mathrm{cn}, 120 \mu \mathrm{mol} ;\left[\mathrm{d}_{3}\right] \mathrm{C}_{3} \mathrm{cn}, 24 \mu \mathrm{mol} ;\left[\mathrm{d}_{9}\right] \mathrm{C}_{8} \mathrm{cn}$, $\left.12 \mu \mathrm{mol} ;\left[\mathrm{d}_{9}\right] \mathrm{C}_{16} \mathrm{cn}, 24 \mu \mathrm{mol}\right)$ were added, plus $500 \mathrm{ml}$ of methanol to each sample. The plates were placed on an orbital shaker (setting $750 \mathrm{rpm}$ ) for $30 \mathrm{~min}$ and then sonicated for $15 \mathrm{~min}$ (sonic bath. 175SR). The plates were returned to the shaker for an additional $2 \mathrm{~h}$ and sonicated again for another $30 \mathrm{~min}$. The filter discs from the card punch were removed and the resulting eluate was evaporated under air at $45^{\circ} \mathrm{C}$ until dry.

Derivatization process. An amount of $50 \mathrm{ml}$ of $1 \mathrm{M}$ Butanolic $\mathrm{HCl}$ was added to each sample and incubated at $60^{\circ} \mathrm{C}$ for $15 \mathrm{~min}$. Samples were immediately returned to the fume cupboard and evaporated under air at $45^{\circ} \mathrm{C}$ until dry and re-dissolved in $100 \mathrm{ml}$ of $70 \%(\mathrm{v} / \mathrm{v})$ acetonitrile in water prior to analysis by ESI -MS/MS.

Tandem mass spectrometry (MS/MS) analysis. The blood analysis for acylcarnitines was performed by using the following scan function: parents of $m / z 85$, scan range $200-500(\mathrm{~m} / \mathrm{z})$, collision energy $25 \mathrm{eV}$, cone voltage $30 \mathrm{~V}$, scan time $2.0 \mathrm{sec}$, interscan time $0.1 \mathrm{sec}$, collision gas Argon, collision gas pressure 1.6-2 x $10^{-3}$ mBar. All analyses were performed by using a Quattro II, triple quadrupole tandem mass spectrometer (Micromass, Manchester, UK) equipped with an ion spray source (ESI) and a micromass MassLynx data system. The samples were introduced into the mass spectrometer source by using a Jasco AS980 autosampler and a Jasco PU980 HPLC pump. For these kinds of works, the use of selected reaction monitoring for each analyte could provide better quantification data; however, analysis for acylcarnitines using parents of $\mathrm{m} /$ $\mathrm{z} 85$ is the routine method when analyzing samples from patients, then we adopted this scan function.

Analysis of carnitine and acylcarnitine leves in red blood cells. Blood samples $(2 \mathrm{ml})$ collected with and without anticoagulant were centrifuged $(2300 \mathrm{~g}$ x 5 min) and the serum or plasma was retained for acylcarnitine analysis. The pellet was resuspended to the volume of $2 \mathrm{ml}$ in each of the following saline $(\mathrm{NaCl})$ solutions: $0.9 \%(\mathrm{w} / \mathrm{v}) \mathrm{NaCl}$ (i.e., $0.9 \mathrm{~g} / \mathrm{dl}$ ); $0.75 \%$ (w/v) $\mathrm{NaCl}$ (i.e., $0.75 \mathrm{~g} / \mathrm{dl}$ ); $0.65 \%$ (w/v) NaCl (i.e., $0.65 \mathrm{~g} / \mathrm{dl}) ; 0.55 \%$ (w/v) $\mathrm{NaCl}$ (i.e., $0.55 \mathrm{~g} / \mathrm{dl}$ ); $0.5 \%$ (w/v) $\mathrm{NaCl}$ (i.e., $0.5 \mathrm{~g} / \mathrm{dl}$ ); $0.45 \%$ (w/v) $\mathrm{NaCl}$ (i.e., $0.45 \mathrm{~g} / \mathrm{dl}$ ); $0.4 \%$ (w/v) NaCl (i.e., $0.4 \mathrm{~g} / \mathrm{dl}) ; 0.3 \%$ (w/v) $\mathrm{NaCl}$ (i.e., $0.35 \mathrm{~g} / \mathrm{dl}) ; 0.3 \%$ (w/v) $\mathrm{NaCl}$ (i.e., $0.33 \mathrm{~g} / \mathrm{dl}$ ); $0.3 \%$ (w/v) $\mathrm{NaCl}$ (i.e., $0.3 \mathrm{~g} / \mathrm{dl}$ ); $0 \%$ (w/v) $\mathrm{NaCl}$ (i.e., 0 $\mathrm{g} / \mathrm{dl})$. Samples were centrifuged $(2,300 \mathrm{~g}$ x $5 \mathrm{~min})$ and the procedure was repeated twice. The final pellet was resuspended in PBS for card preparation and tandem 
Table 1

Concentration of carnitine and acylcarnitines in reconstituted red blood cell samples washed with different concentrations of saline solution

\begin{tabular}{cccccl}
\hline \multicolumn{7}{c}{ \% of analyte relative to whole blood } & & & \\
\hline Saline $\mathbf{N a C l}(\mathbf{g} / \mathbf{d} \mathbf{l})$ & Free carnitine & $\mathbf{C}_{\mathbf{2}} \mathbf{c n}$ & $\mathbf{C}_{8} \mathbf{C n}$ & $\mathbf{C}_{\mathbf{1 6}} \mathbf{c n}$ & $\mathbf{C}_{\mathbf{1 8}} \mathbf{c n}$ \\
\hline 0.9 & 53.3 & 49.4 & 49 & 86.0 & 64 \\
0.75 & 38.8 & 42.4 & 43.2 & 85.0 & 62 \\
0.65 & 39.2 & 45.0 & 45.4 & 87.5 & 60 \\
0.55 & 39.8 & 47.3 & 46.5 & 75.0 & 60 \\
0.5 & 41.1 & 48.0 & 47.0 & 76.4 & 61 \\
0.45 & 37.9 & 48.6 & 47.9 & 76.4 & 59.8 \\
0.4 & 36.1 & 45.0 & 44.0 & 76.4 & 60 \\
0.35 & 27.1 & 34.1 & 35.3 & 56.0 & 55.7 \\
0.33 & 20.9 & 33.5 & 32.5 & 31.9 & 50.1 \\
0.3 & 19.0 & 33.5 & 34.0 & 32.0 & 38 \\
0 & 19.3 & 34.0 & 34.0 & 30.0 & 34.5 \\
\hline
\end{tabular}

Abbreviations: $\mathrm{C}_{2} \mathrm{cn}$, acetylcarnitine; $\mathrm{C}_{16} \mathrm{cn}$, hexadecanoylcarnitine; $\mathrm{C}_{18} \mathrm{cn}$, octadecanoylcarnitine; ud, undetectable.

mass spectrometry analysis. All the samples were extracted and free carnitine and acylcarnitines were analysed. The procedure was performed five times for each sample. Statistical comparisons were performed by using one-way ANOVA (SigmaStat version 3.1 statistical software), followed by Dunnett's test; $p<0.05$ was considered significant. According to article 11 on its literal a. from resolution number 8430 promulgated by the Ministry of Health for scientific, technical and administrative guidelines for health research, the present study is considered without risk. The study was approved by the corresponding ethical committee.

\section{RESULTS}

The results obtained for the different saline solutions are shown in Table 1. It was found that carnitine, as well as short-chain, medium-chain and long-chain acylcarnitines remain in red blood cells at average percentages of $19.3,34,34$, and $32 \%$, respectively, in a complete hypotonic solution. It is evident that most acylcarnitines are associated with blood cells and this may have diagnostic implication as to whether whole blood or plasma/serum is the preferred sample for acylcarnitine analysis. It is clear that with decreasing saline concen- tration the percentage of the remaining free carnitine and acylcarnitines in the washed cell preparation decreases, but this is probably due to the fact that at lower saline concentrations $(<0.4)$ some degree of haemolysis occurs with the resulting leakage of carnitine species in the matrix. Significant differences were found for carnitine and acylcarnitine levels in blood washed with an isotonic solution compared to its levels using several hypotonic solutions $(\mathrm{p}<0.05)$.

\section{DISCUSSION}

It is unexpected to find carnitine and acylcarnitines remaining in $\mathrm{RBC}$ because of the absence of mitochondria and because they are energetically independent of fatty-acid oxidation, with no demand for classical carnitine-mediated fatty-acid transport. However, there have been reports of the activity of carnitine palmitoyltransferase as the essential enzyme for the physiological expression of deacylationreacylation process, within the phospholipid fatty acid membrane of human erythrocytes ${ }^{14,15}$. The results, however, seem to have a far more important diagnostic implication in that although free carnitine and shortchain acylcarnitine are distributed equally between 
plasma and blood cells, long-chain acylcarnitines are more associated with the latter. Serum carnitine concentrations reflect less than $0.5 \%$ of the total body carnitine pool of which $98 \%$ is represented by the muscle mass, the remaining $1.5 \%$ being distributed between the different organ systems and blood cells ${ }^{16}$. The contribution of red blood cell to whole blood level of carnitine increased significantly at delivery ${ }^{17}$. However according to Mares-Perlman et al. ${ }^{18}$, carnitine content found in red blood cells represents $73.6 \pm 4 \%$ of whole-blood carnitine by human preterm neonates at birth but declined to $42.2 \pm 14.1 \%$ by day 14 . This finding agrees with the percentage found in the present study, and then it is possible to postulate that after this day this percentage remains constant even to adulthood.

There is a close correlation between the plasma and muscle carnitine levels, but carnitine in red blood cells seems to represent a carnitine compartment of its own. Carnitine level in red blood cells is probably less related with fatty-acid metabolism of the mitochondrial than with cell-membrane stabilization or buffer function for Na-K-ATPase ${ }^{19}$. The role of the carnitine system is to maintain homeostasis in the acyl-CoA pools of the cell, keeping the acyl-CoA/CoA pool constant even under conditions of very high turnover of the acyl-CoA ${ }^{20}$. The enzyme carnitine palmitoyltransferase (CPT) properties and locations are consistent with this ${ }^{21}$. Above all, the carnitine derivatives can be moved across intracellular barriers, so the carnitine system provides a shuttle mechanism between microsomes, peroxisomes, and mitochondria for complex lipid-synthetic and breakdown pathways ${ }^{22}$. However, it was also demonstrated that the acyl-carnitine pool could act as a source of acyl groups, via the CoA pool, for the incorporation into lipids when energy, required to activate free fatty acids, is limited ${ }^{23}$.

\section{CONCLUSION}

Carnitine, along with short-chain, medium-chain and long-chain acylcarnitines remain in red blood cells at average percentages of $19.3,34,34$, and $32 \%$, respectively, after washing with a total hypotonic solution. Although some researchers recommend using serum or plasma to measure these metabolites, we recommend using whole blood.
Conflict of interest. None of the authors has conflicts of interest related to this study.

\section{REFERENCES}

1. Millington DS, Kodo N, Norwood DL, Roe CR. Tandem Mass Spectrometry: A new method for acylcarnitine profiling with potential for neonatal screening for inborn errors of metabolism. J Inher Metab Dis. 1990; 13: 321-4.

2. Millington DS, Kodo N, Terada N, Roe D, Chace DH. The analysis of diagnostic markers of genetic disorders in human blood and urine using tandem mass spectrometry with liquid secondary ion mass spectrometry. Int J Mass Spect Ion Proc. 1999; 111: 211-28.

3. Levy PA. Inborn errors of metabolism: part 1: overview. Pediatr Rev. 2009; 30: 131-7.

4. Sahai I, Marsden D. Newborn screening. Crit Rev Clin Lab Sci. 2009; 46: 55-82.

5. Chalcraft KR, Britz-McKibbin P. Newborn screening of inborn errors of metabolism by capillary electrophoresis-electrospray ionization-mass spectrometry: a second-tier method with improved specificity and sensitivity. Anal Chem. 2009; 81: 307-14.

6. Artuch Iriberri R, Moreno J, Puig R, Quintana M, Montero R, Ormazábal A, et al. Laboratory diagnosis of rare diseases $A n$ Sist Sanit Navar. 2008; 31 (Suppl 2): 91-103.

7. Agarwal RL, Muranjan MN. Diagnostic practice for organic acidemias: barriers to early diagnosis. Arch Dis Child. 2008; 93: 1000 .

8. Vianey-Saban C, Guffon N, Delolne F, Guibaud P, Mathieu M, Divry P. Diagnosis of inborn errors of metabolism by acylcarnitine profiling in blood using tandem mass spectrometry. J Inher Metab Dis. 1997; 20: 411-44.

9. Van Hove JL, Zhang W, Kahler SG, Roe CR, Chen YT, Terada N, et al. Medium-chain acyl-CoA dehydrogenase (MCAD) deficiency: diagnosis by acylcarnitine analysis in blood. Am J Hum Genet. 1993; 52: 958-66.

10. Millington DS, Terada N, Chace DH, Chen YT, Ding JH, Kodo $\mathrm{N}$, et al. The role of tandem mass spectrometry in the diagnosis of fatty acid oxidation disorders. In: Coates PM, Tanaka K (eds.). New developments in fatty acid oxidation. New York: Wiley-Liss; 1992. p. 339-54.

11. Libert R, Van Hoof F, Thillaye M, Vincent MF, Nassogne $\mathrm{MC}$, Stroobant V, et al. Identification of new medium-chain acylcarnitines present in urine of a patient with medium-chain acyl-CoA dehydrogenase deficiency. JInher Metab Dis. 1999; 22: 9-18.

12. Shigmatsu Y, Hata I, Nakai A, Kikawa Y, Sudo M, Tanaka Y, et al. Prenatal diagnosis of organic acidemias based on amniotic fluid levels of acylcarnitines. Pediatr Res. 1996; 39: 680-4.

13. Rashed MS, Ozand PT, Bennet MJ, Barnard JJ, Govindaraza DR, Rinaldo P. Inborn errors of metabolism diagnosed in sudden death cases by acylcarnitine analysis of postmorten bile. Clin Chem. 1995; 41: 1109-14.

14. Arduini A, Mancinelli G, Radtti GL, Dottori S, Molajoni F, Ramsay RR. Role of carnitine and carnitine palmitoyl- 


\section{Colombia Médica}

transferase as integral components of the pathway for membrane phospholipid fatty acid turnover in intact human erythrocytes. J Biol Chem. 1992; 267: 12673-81.

15. Arduini A, Tyurin V, Tyuruna Y, Arrigoni-Martinelli E, Molajoni F, Dottori S, et al. Acyl-trafficking in membrane phospholipid fatty acid turnover: the transfer of fatty acid from the acyl-L-carnitine pool to membrane phospholipid in intact human erythrocytes. Biochem Biophys Res Commun. 1992; 187: 353-8.

16. Borum PJ, York CM, Bennet SG. Carnitine concentration of red blood cells. Am J Clin Nutr. 1985; 41: 653-6.

17. Schoderbeck M, Auer B, Legenstein E, Genger H, Sevelda P, Salzer $\mathrm{H}$, et al. Pregnancy-related changes of carnitine and acylcarnitine concentrations of plasma and erythrocytes. $J$ Perinat Med. 1995; 23: 477-85.

18. Mares-Perlman JA, Farrel PM, Gutcher GR. Changes in erythrocyte and plasma carnitine concentrations in preterm
Vol. 41 NN$^{\circ}$ 4, 2010 (Octubre-Diciembre)

neonates. Am J Clin Nutr. 1986; 43: 77-84.

19. Reichmann H, van Lindeneiner N. Carnitine analysis in normal human red blood cells, plasma and muscle tissue. Europ Neurol. 1994; 34: 40-3.

20. Vessey DA, Chen WW, Ramsay RR. Effect of carboxylic acid xenobiotics and their metabolites on the activity of carnitine acyltransferases. Biochem J. 1991; 279 (Pt 3): 895-7.

21. Ramsay RR, Arduini A. The carnitine acyltransferases and their role in modulating acyl-CoA pools. Arch Biochem Biophys. 1993; 302: 307-14.

22. Igal RA, Wang P, Coleman RA. Triacsin C blocks synthesis of glycerolipids and cholesterol esters but not recycling of fatty acid into phospholidpid: evidence for functionally separate pools of acyl-CoA. Biochem J. 1997; 324: 529-34.

23. Ramsay RR. The carnitine acyltransferases: modulators of acyl-CoA-dependent reactions. Biochem Soc Trans. 2000; 28: $182-6$. 